\title{
Peran Pembina Pramuka dalam Menanamkan Kepedulian Sosial Siswa di MTsN 2 Bondowoso Tahun 2019
}

\section{The Role of the Scout Counter in Implementing Students Social Carefulness in MTsN 2 Bondowoso 2019}

\author{
Muhammad Junaedi 1
}

Email : muhammadjunaedi560@gmail.com 1 SMA Nurul Ma'rifah

\section{INFORMASI ARTIKEL}

Diterima: February 00, 00

Direvisi: March 00, 00

Publikasi Online: April 00, 00

\section{KATA KUNCI}

Pramuka, Kepedulian Sosial

\section{A B S T R A C T}

Instilling social awareness is an important thing to be instilled in students to foster feelings and behavior of caring for others. Instilling social awareness through scout extracurricular activities at MTsN 2 Bondowoso has an important role in developing positive attitudes, leadership characters and caring for others. This research is a qualitative research and the type of research is descriptive. Data collection techniques using non-participant observation techniques, interviews and documentation. Analysis of the data using the interactive model of Miles and Huberman. The validity of using triangulation of sources and techniques. The results of this study are: 1). inculcating student social awareness; (a) through habituation such as greeting each other, say hello, pay infaq, do charity work and pray for a sick friend; (b) training activities such as, work together and help each other in pioneering, setting up a tent and simulating First Aid In Accident; (c) work programs such as: social services, sowing flowers, raising funds for victims of natural disasters and distributing 1000 zakat; 2) supporting factors for inculcating student social awareness, that is: (a) the existence of scout coaches who can guide and teach about manners to students with mutual respect and help each other; (b) the presence of a teacher, who provides direction and motivation to students; (c) the role of parents who give permission to their children in participating in scouting activities and participating in material matters

\section{A B S T R A K}

Penanaman kepedulian sosial merupakan hal yang penting ditanamkan pada diri siswa untuk menumbuhkan perasaan dan tingkahlaku peduli terhadap orang lain. Penanaman kepedulian sosial melalui kegiatan ekstrakurikuler pramuka di MTsN 2 Bondowoso memiliki peran penting dalam upaya mengembangkan sikap positif, karakter kepemimpinan dan kepedulian terhadap sesama. Penelitian ini merupakan penelitian kualitatif dan jenis 
penelitiannya deskriptif. Teknik pengumpulan data menggunakan teknik observasi non partisipan, wawancara dan dokumentasi. Analisis data menggunakan model interaktif Miles dan Huberman. Keabsahan menggunakan triangulasi sumber dan teknik. Hasil penelitian ini yaitu: 1) penanaman kepedulian sosial siswa; (a) melalui pembiasaan seperti saling mengucapkan salam, tegur sapa, membayar infaq, kerja bakti dan mendo'akan teman yang sakit; (b) kegiatan latihan seperti, saling kerja sama dan saling membatu dalam pembuatan pionering, mendirikan tenda dan simulasi Pertolongan Pertama Pada Kecelakaan; (c) program kerja seperti: bakti sosial, tabur bunga, penggalangan dana untuk korban bencana alam dan pembagian 1000 zakat; 2) faktor pendukung penanaman kepedulian sosial siswa yaitu: (a) keberadaan pembina pramuka yang dapat membimbing dan mengajarkan tentang sopan santun kepada siswa dengan saling menghormati dan saling tolong-menolong (b) keberadaan guru, yang memberikan arahan dan motivasi pada siswa (c) peran orang tua yang memberikan izin pada anaknya (siswa) dalam megikuti kegiatan-kegiatan pramuka dan ikut berpartisipasi dalam hal material.

(c) Heritage: Journal of Social Studies Institut Agama Islam Negeri Jember, Indonesia https://doi.org/ 10.xxxx/xxxx

This is an open access article under the CC-BY-SA license

\section{Pendahuluan}

Kepedulian merupakan suatu perasaan moral yang ada di setiap seseoran untuk bersikap dan bertindak membantu atau menolong orang lain. Kepedulian menunjukkan pada keadaan individu atau kelompok yang didasarkan pada perasaan moral dan kepercayaan yang dianut bersama, serta diperkuat oleh pengalaman emosional bersama. Tindakan sengaja untuk memberikan ketenangan dan mengatasi kesulitan yang ada pada orang lain didorong oleh rasa persamaan kemanusiaan, inilah yang menyebabkan timbulnya rasa kepedulian. Eni Purwati, dkk mengungkapkan, (2012 : 155) Kepedulian sosial ialah perasaan bertanggung jawab atas kesulitan yang dihadapi oleh orang lain dimana seseorang terdorong untuk membantu mengatasinya. Perkembangan ilmu pengetahuan dan teknologi yang sangat pesat saat ini, seakan merubah pola dan tingkahlaku masyarakat khususnya generasi muda sebagai penerus bangsa. Kenakalan remaja, tawuran antar pelajar, diskriminasi sosial bahkan pembunuhan, seakan menggambarkan bahwa masyarakat mengalami krisis moral dan sikap kepedulian antar sesama.

Dihadapkan pada fakta seperti itu, selain dengan menggunakan pembelajaran di kelas, penanaman nilai-nilai positif perlu dicarikan alternatif lain melalui kegiatan pendidikan di luar jam pelajaran sekolah, yaitu melalui ekstrakurikuler. Zainal Aqib \& 
Sujak, menyatakan (2011: 68). Ekstrakurikuler adalah kegiatan pendidikan di luar jam pelajaran yang ditujukan untuk membantu perkembangan siswa sesuai dengan kebutuhan, potensi, bakat, dan minat mereka melalui kegiatan yang secara khusus diselenggarakan oleh pendidik atau tenaga kependidikan yang berkemampuan dan berkewenangan di sekolah. Andri, Bob, Suardi, menyatakan ( 2014 : 413 Kepramukaan termasuk pendidikan non formal yang sering disebut dengan ekstrakulikuler atau kegiatan pendidikan yang dilaksanakan diluar jam sekolah. Sesuai dengan Undang-Undang Republik Indonesia Nomor 12 Tahun 2010 tetang Gerakan Pramuka, gerakan pramuka adalah "organisasi yang dibentuk oleh pramuka untuk menyelenggarakan pendidikan kepramukaan.

Kegiatan kepramukaan merupakan suatu proses pendidikan dalam bentuk kegiatan bagi anak atau remaja yang dilaksanakan di luar pendidikan keluarga yang menggunakan prinsip dasar kepramukaan. Sarkonah mengatakan (2012 : 3) kepramukaan adalah proses pendidikan di luar lingkungan sekolah dan di luar lingkungan keluarga, dalam bentuk kegiatan menarik, menyenangkan teratur, praktis yang dilakukan di alam terbuka dengan prinsip dasar kepramukaan dan metode kepramukaan yang sasaran akhirnya adalah pembentukan watak, ahlak, kepedulian dan budi pekerti luhur.

Kegiatan ekstrakurikuler pramuka yang dapat menanamkan kepedulian sosial siswa di MTsN 2 Bondowoso, mengadakan kegiatan bakti sosial, sebagai wujud dari kepedulian terhadap sesama, tabur bunga merupakan bentuk cinta dan mengenang parah pahlawan yang telah gugur, gladian pinru, latihan gabungan (LATGAB), dan pelatihan-pelatihan struktur muda, sehingga anggota gerakan pramuka di MTsN 2 Bondowoso memiliki jiwa kepemimpinan yang tinggi dan rasa peduli terhadap lembaga, teman dan masyarakat.

Pramuka MTsN 2 Bondowoso merupakan salah satu contoh pramuka aktif yang berada di Kwartir Cabang Bondowoso, hal tersebut dapat dilihat dari prestasi yang telah dicapai pramuka MTsN 2 Bondowoso. Mulai dari tingkat Kwartir Ranting (tingkat kecamatan), Kwartir Cabang (tingkat kabupaten), dan Kwartir Daerah (tingkat provinsi). Selain itu keikut sertaan atau partisipasi kegiatan Kwartir Cabang, Kwartir Daerah, Raimuna nasional dan Jambore nasional merupakan bentuk keaktifan pramuka yang ada di MTsN 2 Bondowoso. Kegiatan ekstrakurikuler pramuka berperan penting dalam penanaman kepedulian sosial siswa yang ada di MTsN 2 Bondowoso.

Seperti yang disampaikan oleh Kak Eska selaku pembina pramuka di MTsN 2 Bondowoso mengatakan (10 Mei 2019).

Kepedulian sosial sangat penting di tanamkan pada diri siswa agar siswa disini mas memiliki kepekaan terhadap sesama, sehingga dengan adanya kegiatankegiatan ekstrakurikuler pramuka siswa merasa terbantu dalam mengembangkan 
dan menumbuhkan kepedulian sosial seperti dibiasakan saling kerjasama antar teman pada saat latihan pramuka mengadakan bakti sosial dan pembagian 1000 zakat.

Disitulah pentingnya kegiatan ekstrakurikuler pramuka MTsN 2 Bondowoso dalam penanaman jiwa kepedulian sosial. Uraian latar belakang tersebut menarik untuk diteliti lebih lanjut sehingga peneliti peneliti mengambil judul "Penanaman kepedulian sosial siswa melalui kegiatan ekstrakurikuler pramuka di MTsN 2 Bondowoso Tahun 2019.

\section{Metode Penelitian}

Pendekatan dan Jenis Penelitian

Pendekatan penelitian yang digunakan dalam penelitian ini adalah pendekatan kualitatif. Penelitian kualitatif menghasilkan data deskriptif berupa kata-kata tertulis dari orang-orang atau prilaku yang dapat diamati (Moleong, 2005). Penelitian kualitatif dilakukan karena peneliti ingin memahami fenomena tentang apa yang dialami oleh subyek penelitian misalnya prilaku, sosial, tindakan dan lain sebagainya, secara holistik dan dengan cara deskriptif dalam bentuk kata-kata dan bahasa, pada suatu konteks khususnya yang alamiah dan dengan berbagai metode alamiah. ${ }^{1}$ Hal ini sejalan dengan pendapat Sudarwan Danim bahwa penelitian kualitatif dimaksudkan untuk mendeskripsikan suatu situasi atau area populasi tertentu yang bersifat faktual secara sistematis dan akurat. Penelitian kualitatif ini untuk memotret fenomena individual, situasi, atau kelompok tertentu yang terjadi secara kekinian (Sudarwan, 2002).

Jenis penelitian ini kualitatif deskriptif karena penelitian ini bertujuan untuk menggambarkan dan mendeskripsikan karaktristik dari fenomena. Penelitian kualitatif deskriptif biasanya untuk menjawab penelitian yang menyangkut pertanyaan. Salah satu cirri utama dari deskriptif adalah paparannya yang bersifat naratif. Nazir berpendapat bahwa metode deskriptif adalah suatu metode dalam meneliti suatu kelompok manusia, suatu obek, suatu set kondisi, suatu sistem pemikiran, dan lain-lain (Andi, 2011).

Lokasi Penelitian.

Lokasi penelitian ini adalah MTsN 2 Bondowoso, yang terletak di J1. MT. Haryono No. 44 Bondowoso Provinsi Jawa Timur. Alasan dipilihnya MTsN 2 Bondowoso sebagai tempat penelitian yaitu:

1. Terdapat keunikan kegiatan pramuka seperti kegiatan bakti sosial, sebagai wujud dari kepedulian terhadap sesama, tabur bunga sebagai bentuk cinta dan mengenang parah 
pahlawan yang telah gugur, gladian pinru, latihan gabungan (LATGAB), dan pelatihanpelatihan struktur muda.

2. Keunikan lain dalam kepedulian sosial yaitu adanya kerjasama pramuka MTsN 2 Bondowoso dengan Pondok Pesantren Nurul Jadid yaitu program tahunan berupa bakti sosial dan pembagian sakat pada masyarakat.

3. Prestasi yang telah dicapai pramuka MTsN 2 Bondowoso. Mulai dari tingkat Kwartir Ranting (tingkat kecamatan), Kwartir Cabang (tingkat kabupaten), Kwartir Daerah (tingkat provinsi) selalu membawa juara, selain itu keikut sertaan atau partisipasi kegiatan Kwartir Cabang, Kwartir Daerah, Raimuna nasional dan Jambore nasional.

Subyek Penelitian.

Subjek penelitian adalah pihak-pihak yang dijadikan informan dalam sebuah penelitian. Penelitian ini menggunakan teknik purposive dalam penentuan subyek penelitian. Purposive adalah pengambilan informan atau sumber data dengan pertimbangan tertentu. Pertimbangan tertentu ini misalnya orang tersebut yang dianggap paling tau dan paham tentang apa yang kita harapkan atau mungkin dia sebagai penguasa sehingga memudahkan peneliti menjelajahi obyek atau situasi sosial yang di teliti (Sugiyono, 2012). Subyek penelitian atau informan yang di pilih dalam penelitian ini adalah pembina pramuka MTsN 2 Bondowoso, kepala sekolah MTsN 2 Bondowoso, pembantu Pembina pramuka MTsN 2 Bondowoso dan siswa MTsN 2 Bondowoso

Teknik pengumpulan data

Pengumpulan data dalam penelitian ini merupakan langkah yang paling strategis, karena tujuan utama dalam penelitian adalah mendapatkan data. Teknik pengumpulan data yang digunakan pada penelitian ini sebagai berikut:

\section{Observasi (pengamatan)}

Observasi atau disebut pula dengan pengamatan merupakan pemusatan perhatian pada suatu obyek dengan menggunakan seluruh alat indra (Arikunto, 2006). Jadi observasi adalah suatu metode atau cara menganalisis serta melakukan pengamatan secara sistematis mengenai fenomena sosial kemudian dilakukan pencatatan. Observasi yang digunakan dalam penelitian ini adalah observasi non partisipan untuk mengamati peran pembina pramuka dalam menanamkan kepedulian sosial yang dilakukaan yaitu peran pembina pramuka sebagai pembimbing, motivator dan perancang program kegiatan dalam gerakan pramuka. Metode ini digunakan oleh peneliti untuk mengungkap Lokasi MTsN 2 Bondowoso, penanaman kepedulian sosial siswa melalui kegiatan ekstrakurikuler pramuka, faktor pendukung penanaman 
kepedulian sosial siswa melalui kegiatan ekstrakurikuler pramuka dan aktivitas ekstrakurikuler pramuka dalam membentuk kepedulian sosial siswa.

2. Wawancara

Wawancara merupakan sebuah percakapan antara dua orang atau lebih, yang pertanyaannya diajukan oleh peneliti kepada subyek atau sekelompok subyek penelitian untuk dijawab (Sudarwan, 2002). Penelitian ini menggunakan wawancara yang terbuka atau bebas terpimpin. Pada wawancara ini peneliti memberikan kebebasan diri dan mendorongnya untuk berbicara secara luas dan mendalam. Tujuan dari wawancara ini untuk mendapatkan data tentang penanaman kepedulian sosial siswa melalui kegiatan ekstrakurikuler pramuka di MTsN 2 Bondowoso, faktor pendukung penanaman kepedulian sosial siswa melalui kegiatan ekstrakurikuler pramuka di MTsN 2 Bondowoso

3. Dokumentasi

Dokumen adalah catatan peristiwa yang sudah berlalu. Dokumentasi bisa berbentuk tulisa, gambar, atau karya monumental dari seseorang. Studi dokumen merupakan pelengkap dari penggunaan metode observasi dan wawancara dalam penelitian kualitatif (Sugiyono, 2012). Data yang diperoleh melalui dokumentasi yaitu letak geografis MTsN Bondowoso, sejarah MTsN 2 Bondowoso, Visi dan misi MTsN 2 Bondowoso, struktur organisasi MTsN 2 Bondowoso, struktur organisasi kepramukaan MTsN 2 Bondowoso, saran dan prasarana MTsN 2 Bondowoso dan tenaga pendidik dan kependidikan MTsN 2 Bondowoso

Analisis Data

Analisis data merupakan proses yang berkelanjutan yang membutuhkan refleksi terus menerus terhadap data, mengajukan pertanyaan-pertanyaan analitis, dan menulis catatan singkat sepanjang penelitian. Analisis data adalah proses mengatur urutan data, mengorganisasikannya kedalam suatu pola, kategori dan satuan uraian dasar sehingga dapat dirumuskan hipotesis kerja seperti yang disarankan oleh data (Moleong, 2005). Analisis data yang digunakan dalam penelitian ini menggunakan analisis model Miles dan Huberman yaitu melalui data collection, data condensation, data display dan data conclution drawing / verification (Miles et al., 2014). Berikut penjelasan analisis data model Miles dan Huberman:

\section{a. Data collection (Pengumpulan data)}

Pengumpulan data merupakan dokumen sebagai bahan dalam menghasilkan informasi sesuai data yang diinginkan. Dalam kegiatan ini tentusaja termasuk pencatatan adminitrasi dari dokumen sehingga bias diketahui jumlah dokumen 
yang tersedia sehingga memudahkan pencariaan kembali dokumen tersebut jika di perlukan sehingga data colletion merupakan kumpulan atau keseluruhan data.

b. Data condensation (Kondensasi data)

Pada buku Miles \& Huberman ditulis "Data condensation refers to the process of selecting, focusing, simplifying, abstracting, and/or transforming the data that appear in the full corpus (body) of written-up field note,interview, transcripts, documents, and other empirical materials. Kondensasi data adalah proses menyeleksi, memfokuskan, menyederhanakan, mengabstraksi, dan mengubah catatan lapangan, transkrip wawancara, dokumen, dan materi (temuan) empiris lainnya. Kondensasi (pengembunan) data berarti mengubah data yang sebelumnya menguap menjadi lebih padat. Letak perbedaan antara reduksi dengan kondensasi terletak pada cara penyederhanaan data. Reduksi cenderung memilah kemudian memilih, sedangkan kondensasi menyesuaikan seluruh data yang dijaring tanpa harus memilah (mengurangi) data. Kondensasi data merujuk kepada proses menyeleksi, memfokuskan, menyederhanakan, mengabstraksi dan mentransformasi data yang terdapat pada catatan lapangan maupun transkrip dalam penelitian ini diuraikan sebagai berikut:

1) Selecting

Menurut Miles dan Huberman, peneliti harus bertindak selektif, yaitu menentukan dimensi-dimensi mana yang lebih penting, hubungan-hubungan mana yang mungkin lebih bermakna, dan sebagai konsekuensinya, informasi apa yang dapat dikumpulkan dan dianalisis, pada tahapan ini peneliti mengumpulkan semua informasi yang berkaitan dengan judul yaitu tentang penanaman kepedulian sosial siswa melalui kegiatan ekstrakurikuler pramuka, peneliti mengumpulkan seluruh informasi untuk memperkuat penelitian.

2) Focusing

Miles dan Huberman menyatakan bahwa memfokuskan data merupakan bentuk pra-analisis. Pada tahap ini, peneliti memfokuskan data yang berhubungan dengan fokus penelitian. Tahap ini merupakan kelanjutan dari tahap seleksi data. Peneliti hanya membatasi data yang berdasarkan fokus penelitan.

3) Abstracting

Data dalam penelitian ini selanjutnya disederhanakan dan diabstraksikan. Abstraksi merupakan usaha membuat rangkuman yang inti, proses, dan pernyataan-pernyataan yang perlu dijaga sehingga tetap berada di dalamnya. Pada tahap ini, data yang telah terkumpul dievaluasi, khususnya yang 
berkaitan dengan kualitas dan kecukupan data, jika data menunjukkan penanaman kepedulian sosial siswa melalui kegiatan ekstrakurikuler pramuka, dirasa baik dan sudah cukup maka data tersebut digunakan untuk menjawab masalah yang diteliti.

\section{4) Simplifying and Transforming}

Data ditransformasikan dalam berbagai cara, yakni melalui seleksi yang ketat, melalui ringkasan atau uraian singkat, menggolongkan data dalam satu pola yang lebih luas, dan sebagainya.

c. Penyajian data

Setelah langkah pertama telah dilakukan, maka langkah selanjutnya adalah menyajikan data. Penyajian data ini dilakukan dalam bentuk uraian singkat, bagan, hubungan antar kategori (Sugiyono, 2012). Dengan menyajikan data, maka memudahkan peneliti untuk memahami apa yang terjadi, merencanakan kerja selanjutnya berdasarkan apa yang telah dipahami. Dalam tahap ini hasil wawancara, observasi, dan kajian dokumen dikelompokkan sesuai dengan kajian masing-masing.

d. Penarikan kesimpulan

Kesimpulan awal yang dikemukakan masih bersifat sementara, dan berubah bila tidak ditemukan bukti-bukti yang kuat yang mendukung pada tahap pengumpulan data berikutnya. Tetapi apabila kesimpulan yang dikemukakan pada tahap awal didukung oleh bukti-bukti yang valid dan konsisten saat peneliti ke lapangan mengumpulkan data, maka kesimpulan yang dikemukakan merupakan kesimpulan yang kredibel. Kesimpulan yang kredibel adalah kesimpulan yang menjawab atas permasalahan yang menjadi titik fokus peneliti, dari kesimpulan ini, maka ditemukan hasil penemuan peneliti yang sebelumnya belum pernah dikaji oleh siapapun. Seperti temuan yang berupa deskripsi atau gambaran objek yang sebelumnya belum jelas menjadi jelas setelah adanya penelitian yang dilakukan.

Dalam tahap ini peneliti menyimpulkan dari hasil tahap analisis sebelumnya, dan menjawab semua fokus masalah yang menjadi permasalahan dalam penelitian.

Keabsahan Data

Pengecekan keabsahan data dilakukan agar memperoleh hasil yang valid dan dapat dipertanggung jawabkan serta dapat dipercaya oleh semua pihak. Keabsahan data merupakan konsep yang menunjukkan kesahihan dan keadaan data dalam suatu penelitian. Untuk menguji keabsahan data yang diperoleh peneliti menggunakan 
triangulasi. Triagulasi adalah pemeriksaan keabsahan data yang memanfaatkan sesuatu yang lain diluar data itu untuk keperluan pengecekan atau sebagai pembanding terhadap suatu data tersebut. (Moleong, 2005). Triagulasi yang digunakan dalam penelitian ini adalah triangulasi sumber dan teknik

\section{a. Triagulasi Sumber}

Triagulasi sumber yaitu menguji kreadibilitas data yang dilakukan dengan cara mengecek data yang telah diperoleh melalui beberapa sumber. Data yang diperoleh dari pembina pramuka di cek kembali kebenarannya dengan pembantu pembina pramuka, kepala sekolah dan siswa.

\section{b. Triangulasi Teknik}

Triangulasi teknik menguji kredibilitas data dilakukan dengan cara mengecek data kepada sumber yang sama dengan teknik yang berbeda. Misalnya data yang diperoleh dari wawancara pada pembina pramuka lalu dicek dengan observasi, dokumentasi. Bila dengan ketiga teknik pengujian kredibilitas data tersebut menghasilkan data yang berbeda maka peneliti melakukan diskusi lebih lanjut kepada sumber data yang bersangkutan atau yang lain, untuk memastikan data mana yang dianggap benar.

\section{Hasil \& Diskusi}

Pada bagian ini akan membahas tentang keterkaitan antara data yang telah ditemukan di lapangan dengan teori yang relevan. Data yang didapat melalui wawancara, observasi dan dokumentasi akan dianalisis dengan teori. Pembahasan temuan dirinci sesuai dengan fokus penelitian yang telah ditentukan agar mampu menjawab permasalahan yang ada di lapangan. Hasil dan pembahasan temuan dijelaskan sebagai berikut:

1. Penanaman kepedulian sosial siswa melalui kegiatan ekstrakurikuler pramuka di MTsN 2 Bondowoso Tahun 2019.

Berdasarkan temuan yang ada diketahui penanaman kepedulian kepedulian sosial siswa melalui kegiatan ekstrakurikuler pramuka di MTsN 2 Bondowoso Tahun 2019 yaitu; (a) melalui pembiasaan seperti saling mengucapkan salam, tegur sapa, membayar infaq, kerja bakti membersihkan lingkungan sekolah dan sanggar pramuka serta mendo'akan teman yang sakit; (b) melaliu kegiatan latihan rutin misalnya siswa dilatih untuk saling kerja sama dan saling membatu dalam pembuatan pionering, mendirikan tenda dan simulasi Pertolongan Pertama Pada Kecelakaan; (c) melalui program kerja misalnya program bakti sosial di desa-desa terpencil yang ada di Bondowoso, taburbunga dilakukan di makam pahlawan Bondowoso, melakukan penggalangan dana untuk korban bencana alam dan pembagian 1000 zakat yang bekerja sama dengan pondok pesantren Nurul Jadi. 
Pertama; melalui pembiasaan seperti saling mengucapkan salam, tegur sapa, membayar infaq, kerja bakti membersihkan lingkungan sekolah dan sanggar pramuka serta mendo'akan teman yang sakit. Pembiasaan adalah sebuah cara yang dapat dilakukan untuk membiasakan anak didik berfikir, bersikap dan bertindak sesuai dengan tuntunan ajaran agama Islam, Kegiatan spontan adalah kegiatan yang dapat dilakukan tanpa dibatasi oleh waktu, tempat dan ruang hal ini bertujuan memberikan pendidikan secara spontan, terutama membiasakan mengucapkan salam dan bersalaman kepada guru, karyawan dan sesama siswa, bersikap sopan santun, membiasakan menghargai pendapat orang lain Membiasakan menolong atau membantu orang lain (Arief, 2002), Kedua; melaliu kegiatan latihan rutin misalnya siswa dilatih untuk saling kerja sama dan saling membatu dalam pembuatan pionering, mendirikan tenda dan simulasi Pertolongan Pertama Pada Kecelakaan. Hal tersebut senada dengan yang diungkapkan oleh Jana dkk tentangkegiatan yang mencerminkan kepedulian sosial yaitu Kagiatan latihan rutin seperti upacara kegiatan pendidikan kepramukaan diawali dengan upacara pembukaan dan upacara penutupan. Upacara ini bertujuan untuk menanamkan rasa cinta tanah air, jiwa persatuan dan kesatuan, berbangsa, dan bernegara, jiwa 24 pancasila, kedisiplinan, kepedulian sosial, menghayati satya dan darma pramuka, tanggung jawab, serta dapat memimpin dan dipimpin, Mencari jejak, Tanda jejak adalah tanda yang menunjukkan sesuatu, apakah itu arah jalan atau bahkan hal-hal lain tentang peristiwa atau kejadian. Mencari jejak adalah ketrampilan yang harus dimiliki oleh pramuka. Bagi setiap pramuka dituntut untuk waspada terutama apabila berjalan atau melakukan perjalanan. Mencari jejak bertujuan untuk melatih cinta tanah air, peduli lingkungan, kerja sama dan tanggung jawab (Anggadiredja et al., 2017).

Sunardi, juga berpendapat tentang kegiatan pramuka yang dapat menanamkan kepedulian sosial yaitu Berkemah, biasanya perkemahan diadakan sebagai penutup rangkaian kegiatan atau rutinitas lainnya. Materi yang diajarkan disesuaikan dengan tingkat kompetensi yang perluu dikuasai. Banyak manfaat yang dapat diambil dari kegiatan kemah, diantaranya bagi peserta didik adalah: Melatih kemandirian, tanggung jawab, kerja sama, empati, disiplin, Berani dipimpin dan memimpin, Membiasakan diri mendahulukan kepentingan bersama daripada individu. Bagi sangga kerja adalah: Melatih ketrampilan memimpin, Melatih mengatasi masalah, konflik, Bertanggung jawab atas jadwal yang sudah direncanakan.

Pionering (Bidang tali temali) Adalah salah satu teknik pramuka dalam penggunaan peralatan tongkat dan tali yang dirangkai menjadi sebuah model suatu objek. Dalam tali temali kita sering mencampuradukkan antara tali, simpul dan ikatan. 
Hal ini sebenarnya berbeda sama sekali. Tali adalah bendanya. Simpul adalah hubungan antara tali dengan tali. Ikatan adalah hubungan antara tali dengan benda lainnya, misal kayu, balok, bambu dan sebagainya. Pioneering ini bertujuan untuk memberi informasi, ilmu baru, dan mengasah keterampilan peserta dalam membuat sebuah model suatu objek sederhana yang nantinya dapat diaplikasikan dikehidupan pada saat dan sesudah kegiatan kepramukaan. Serta bertujuan untuk melatih ketelitian, kesabaran, kerja sama, percaya diri, dan tanggung jawab. Pertolongan Pertama Pada Kecelakaan (P3K) P3K merupakan salah satu kegiatan kepramukaan yang memberikan bekal peserta didik dalam ketrampilan dan pengetahuan kesehatan yang praktis guna memberikan bantuan pertama kepada orang lain yang sedang mengalami musibah. P3K bertujuan untuk melatih ketelitian, kerja sama, tanggung jawab dan peduli sosial. Ketiga; melalui program kerja misalnya program bakti sosial di desa-desa terpencil yang ada di Bondowoso, taburbunga dilakukan di makam pahlawan Bondowoso, melakukan penggalangan dana untuk korban bencana alam dan pembagian 1000 zakat yang bekerja sama dengan pondok pesantren Nurul Jadi. Selaras dengan pendapat Harpian tentang bakti sosial Bakti sosial atau lebih dikenal sebagai baksos merupakan salah satu kegiatan wujud dari rasa kemanusiaan antara sesama manusia. Bakti Sosial merupakan suatu kegiatan dimana dengan adanya kegiatan ini kita dapat merapatkan kekerabatan antara sesama tanpa ada diskriminasi antara satu denganyang lain, bakti sosial sebagai salah satu dari kegiatan pramuka sangat membantu dalam memberikan pelajaran dan pembentukan kepedulian terhadap sesama. Bakti sosial dapat membantu siswa dalam mewujudkan sikap-sikap positif seperti kepedulian terhadap lingkungan, kepedulian antar sesama baik sebagai individu maupun sebagai kelompok sosial, kemauan untuk berbagi dan berempati, dan memper erat hubungan kekeluargaan (Harpian et al., 2018).

Dari hasil analisis data di atas dapat disimpulkan bahwa bahwa faktor pendukung penanaman kepedulian sosial siswa melalui kegiatan ekstrakurikuler pramuka

2. Faktor pendukung penanaman kepedulian sosial siswa melalui kegiatan ekstrakurikuler pramuka di MTsN 2 Bondowoso Tahun 2019.

Berdasarkan penelitian yang telah dilaksanakan, diketahui bahwa faktor pendukung penanaman kepedulian sosial siswa melalui kegiatan ekstrakurikuler pramuka yaitu (a) keberadaan pembina pramuka yang dapat membimbing dan mengajarkan tentang sopan santun kepada siswa dengan saling menghormati, dan saling tolong-menolong, (b) keberadaan guru merupakan faktor endukung dalam penanaman kepedulian sosial karena guru memberikan arahan dan motivasi pada siswa misalnya arahan yang dilakukan yaitu saling mengingatkan satu sama yang lain baik yang berkaitan dengan 
kegiatan pramuka maupun diluar kegiatan prmuka, (c) orang tua juga merupakan faktor pendukung dalam penanaman kepedulian sosial seperti orang tua memberikan izin pada anaknya (siswa) dalam megikuti kegiatan-kegiatan pramuka yang mencerminkan kepedulian sosial, ikut berpartisipasi dalam hal material seperti ketika ada iyuran dalam kegiatan pramuka Pertama, keberadaan pembina pramuka yang dapat membimbing dan mengajarkan tentang sopan santun kepada siswa dengan saling menghormati, dan saling tolong-menolong. Senada dengan Angga Diredja mengatakan pembina pramuka tingkat pembina pramuka sebagai pembimbing, pemberian bimbingan dan bantuan terhadap anggota pramuka penggalang dengan menggunakan prinsip dasar kepramukaan dan metode kepramukaan, dan sistem among sehingga melalui kegiatan yang disajikan pembina dapat mendidik dan membimbing sikap dan prilaku yang dilandasi kematangan spiritual, emosional, sosial, intelektual dan fisik (Anggadiredja et al., 2011). Selaras dengan peran pembina pramuka yang mencerminkan bahwa pembina pramuka merupakan faktor pendukung yaitu:.

1) Pembina pramuka sebagai kakak yang dapat melindungi dan mendampingi adikadiknya, yang memberikan. kesempatan untuk memimpin dan mengelolah satuannya.

2) Pembina pramuka sebagai mitra, teman yang dapat dipercaya, bersama-sama menggerakkan kegiatan-kegiatan agar menarik, menyenangkan dan penuh tantangan sesuai usia dan golongan.

3) Pembina pramuka sebagai konsultan, tempat bertanya dan berdiskusi tentang berbagai masalah.

4) Pembina pramuka sebagai motivator memotivasi untuk meningkatkan kualitas diri dengan berkreasi, berinovasi, dan aktualisasi diri membangun semagat untuk maju.

5) Pembina pramuka sebagai fasilitator, memfasilitasi kebutuhan dalam kegiatan peserta didik (Anggadiredja et al., 2017)

Kedua; keberadaan guru merupakan seorang pendidik yang dapat mendukung dalam penanaman kepedulian sosial karena guru memberikan arahan dan motivasi pada siswa misalnya arahan yang dilakukan yaitu saling mengingatkan satu sama yang lain baik yang berkaitan dengan kegiatan pramuka maupun diluar kegiatan prmuka. Guru adalah pendidik profesional dengan tugas utama mendidik, mengajar, membimbing, mengarahkan, melatih, menilai, dan mengevaluasi peserta didik pada pendidikan anak usia dini jalur pendidikan formal, pendidikan dasar, dan pendidikan menengah. Ketiga; keberadaan orang tua juga merupakan faktor pendukung dalam penanaman kepedulian sosial seperti orag tua memberikan pendidikan awal pada siswa 
tentang prilaku sosial, orang tua memberikan izin pada anaknya (siswa) dalam megikuti kegiatan-kegiatan pramuka yang mencerminkan kepedulian sosial, ikut berpartisipasi dalam hal material seperti ketika ada iyuran dalam kegiatan pramuka,

Hal ini senada dengan yang di ungkapkan oleh Abu Ahmadi Keluarga merupakan kelomopk sosial pertama dalam kehidupan manusia dimana anak pertamakali mendapatkan pembelajaran, pendudikan dan bimbingan dari orang tua, Peran orang tua dalam perkembangan sikap kepedulian sosial anak merupakan pendekatan yang utama karena orang tua dapat memberikan pendidikan dan mengajarkan tentang sikap peduli terhadap lingkungan keluarga (Ahmadi, 2007).

Dari hasil analisis data di atas dapat disimpulkan bahwa bahwa faktor pendukung penanaman kepedulian sosial siswa melalui kegiatan ekstrakurikuler pramuka adalah keberadaan keberadaan pembina pramuka yang dapat membimbing dan mengajarkan tentang sopan santun kepada siswa dengan saling menghormati, dan saling tolongmenolong, keberadaan guru merupakan seorang pendidik yang dapat mendukung dalam penanaman kepedulian sosial karena guru memberikan arahan dan motivasi. Keberadaan orag tua memberikan pendidikan awal pada siswa tentang prilaku peduli sosial.

\section{Kesimpulan}

Berdasarkan penyajian dan analisis data yang telah dijelaskan mengenai penanaman kepedulian sosial siswa melalui kegiatan ekstrakurikuler pramuka di MTsN 2 Bondowoso tahun 2019 dapat ditarik kesimpulan sebagai berikut:

1. Penanaman kepedulian sosial siswa melalui kegiatan ekstrakurikuler pramuka di MTsN 2 Bondowoso tahun 2019. Pertama; melalui pembiasaan seperti saling mengucapkan salam, tegur sapa, membayar infaq,, kerja bakti membersihkan lingkungan sekolah dan sanggar pramuka serta mendo'akan teman yang sakit; kedua, melaliu kegiatan latihan rutin misalnya siswa dilatih untuk saling kerja sama dan saling membatu dalam pembuatan pionering, mendirikan tenda dan simulasi Pertolongan Pertama Pada Kecelakaan; ketiga, melalui program kerja misalnya program bakti sosial di desa-desa terpencil yang ada di Bondowoso, taburbunga dilakukan di makam pahlawan Bondowoso, melakukan penggalangan dana untuk korban bencana alam dan pembagian 1000 zakat yang bekerja sama dengan pondok pesantren Nurul Jadi.

2. Faktor pendukung penanaman kepedulian sosial siswa melalui kegiatan ekstrakurikuler pramuka di MTsN 2 Bondowoso tahun 2019, yaitu keberadaan pembina pramuka yang dapat membimbing dan mengajarkan tentang sopan santun kepada siswa dengan saling menghormati, dan saling tolong-menolong. Keberadaan 
guru merupakan faktor endukung dalam penanaman kepedulian sosial karena guru memberikan arahan dan motivasi pada siswa misalnya arahan yang dilakukan yaitu saling mengingatkan satu sama yang lain baik yang berkaitan dengan kegiatan pramuka maupun diluar kegiatan prmuka. Orang tua juga merupakan faktor pendukung dalam penanaman kepedulian sosial seperti orang tua memberikan izin pada anaknya (siswa) dalam megikuti kegiatan-kegiatan pramuka yang mencerminkan kepedulian sosial, ikut berpartisipasi dalam hal material seperti ketika ada iyuran dalam kegiatan pramuka

\section{Referensi}

Ahmadi, A. (2007). Psikologi Sosial. Jakarta : Renika Cipta.

Andi, P. (2011). Panduan Kreatif Membuat Bahan Ajar Inovatif: Menciptakan Metode Pembelajaran yang Menarik dan Menyenangkan.Yogyakarta : Diva Press.

Anggadiredja, J. T., Daud, A., Manitis, Y., Iqbal, R. M., Jasmiwarti, \& Setiyo, E. (2011). Panduan Penyelesaian Syarat kecakapan Umum Pramuka Golongan Penggalang. Jakarta : Kwartil Nasional Gerakan Pramuka.

Anggadiredja, J. T., Mursitho, J., Yuliati, S., S., D. K., Jasmiwarti, Prihatmono, T., \& Rifa'i, A. A. (2017). Kursus Mahir Dasar Untuk Pembina Pramuka. Jakarta : Kwartil Nasional Gerakan Pramuka.

Arief, A. (2002). Pengantar Ilmu dan Metodologi Pendidikan Islam. Jakarta : Ciputat Press.

Arikunto, S. (2006). Prosedur Penelitian Suatu Pendekatan Praktis. Jakarta : Rineka Cipta.

Harpian, Asuru, A., \& Nerlin. (2018). Kegiatan Kepramukaan Sebagai Sarana Menumbuhkan Karakter Siswa SMA Negeri 3 Konawe Selatan. SELAMI IPS, 3 (47).

Lestari, H. (2016). Peran Pembina Dalam Kegiatan Organisasi Pramuka di SMA Negeri 4 Magelang. Universitas Negeri Semarang.

Miles, M. B., Huberman, A. M., \& Saldana, J. (2014). Qualitative data analysis A Methods Sourcebook. Amerika. SAGE Publications.

Moleong, L. J. (2005). Metodologi Penelitian Kualitatif. Bandung : Remaja Rosda Karya.

Pambudi, R. W. (2016). Pendidikan Karakter Peduli Lingkungan Melalui Ekstrakulikuler Pramuka di SMP Negeri 1 Sale Kabupaten Rembang. Universitas Negeri Semarang.

Sudarwan, D. (2002). Menjadi Peneliti Kualitatif Ancangan Metodologi, Prestasi, dan Publikasi Hasil Penelitian untuk Mahasiswa dan Penelitian Pemula Ilmu-Ilmu Sosial, Pendidikan, dan Humaniora. Bandung : Pustaka Setia.

Sugiyono. (2012). Metode Penelitian Kuantitatif Kualitatif dan R\&D. Bandung : Alfabeta.

Wardiman, Pujiastuti, W., \& Hasdin. (2017). Peranan Pembina Pramuka Dalam Pembinaan Jiwa Bela Negara Siswa SMP Negeri 3 Palu. Universitas Tadulako. 